\title{
Effect of the Exchanged Cation in an Algerian Montmorillonite Used as a Heterogeneous Catalyst for Biginelli Reaction
}

\author{
Fatiha Belferdi, ${ }^{1,}{ }^{*}$ Farida Bouremmad, ${ }^{2}$ Shalima Shawuti ${ }^{3}$ \\ and Mehmet Ali Gulgun ${ }^{3}$ \\ ${ }^{1}$ Laboratoire de Pharmacologie et de Phytochimie, Université Mohamed Seddik Ben Yahia, Jijel, Algeria. \\ ${ }^{2}$ Laboratoire de l'Interaction des Matériaux et de l'Environnement (LIME) Université Mohamed Seddik Ben Yahia, \\ Jijel, Algeria. \\ ${ }^{3}$ Sabanci University, FENS, Orhanli Tuzla, Istanbul 34956, Turkey. \\ *Corresponding author: E-mail: fbelferdi@gmail.com
}

Received: 07-26-2020

\begin{abstract}
In this work, an Algerian montmorillonite (Mt) is exchanged by different cations from the transition metals family, namely: $\mathrm{Cu}^{2+}, \mathrm{Ni}^{2+}, \mathrm{Cr}^{3+}, \mathrm{Co}^{2+}, \mathrm{Fe}^{2+}$ and $\mathrm{Fe}^{3+}$, it is used as a heterogeneous catalyst for Biginelli reaction. The exchanged cations are known for their catalytic properties in homogeneous catalysis. The main purpose is to study the effect of the exchanged cations on the yield and the kinetics of the reaction. The characterization of montmorillonite was carried out by XRD, which allows us to follow the evolution of the basal spacing $\mathrm{d}_{001}$ as a function of the exchanged cation and to show that the exchange operation has not altered the montmorillonite structure. The cation exchange capacity (CEC) is determined by the titration of the exchanged cation by atomic absorption. The product of the reaction is characterized by NMR, IR and by the determination of the melting point. In addition, the importance of the introduction order of the reagents into the reaction medium has been demonstrated on the yield and the kinetics. Finally, the obtained results show that the exchanged montmorillonite is competitive with other costly heterogeneous and homogeneous catalysts.
\end{abstract}

Keywords: Montmorillonite; heterogeneous catalyst; Biginelli reaction; multi-component reactions (MCRs).

\section{Introduction}

Currently, the chemical industry and in particular the fields of organic and pharmaceutical chemistry are confronted with certain constraints of environmental interests. This requires the adoption of new procedures which respect the environmental and ecological balance while improving the cost and efficiency of the reactions. In this sought-after environmental framework, heterogeneous catalysis greatly contributes to the development of the chemical industry and offers many advantages compared to homogeneous catalysis, because the solid catalyst is easy to recover from the reaction medium and to regenerate and it can also be used in small amounts. ${ }^{1-3}$ Scientific research continues to progress in this area and mainly aims to find new solid catalysts that better meet economic and environmental requirements. In this field common- ly known as green chemistry, montmorillonite which is a material of natural origin, has gained interest for contact and surface phenomena applications such as adsorption for elimination of pollutants and heterogeneous catalysis; this is justified by its abundance and low cost, its effectiveness in developing important specific surfaces area, the presence of electrical charges on its surface and its cation exchange capacity. ${ }^{4-7}$

Montmorillonite is a natural 2/1 type aluminosilicate, consisting of a superposition of sheets each containing an octahedral $\mathrm{AlO}_{6}$ layer sandwiched between two tetrahedral $\mathrm{SiO}_{4}$ layers. The vertices of $\mathrm{AlO}_{6}$ layer are occupied by oxygen or by hydroxides and the center by aluminum, while the vertices of $\mathrm{SiO}_{4}$ layer are occupied by oxygen and the center by silicon. ${ }^{8}$ Each sheet has a negative charge due to the substitution of the central atoms of these layers by atoms of lower charges; the negative charge 
thus generated is balanced by the so-called compensating cation, occupying the interfoliar space. ${ }^{9}$

Generally, montmorillonites can be subjected to different treatments which lead to many structural modifications having a direct effect on their properties and thus on their applications in various fields. The cation exchange property, representing the quantity of cations which equilibrates the negative charge of the sheets, expressed in meq/100 $\mathrm{g}$ of clay, is very interesting as long as the interfoliary cations (generally $\mathrm{Na}^{+}$and $\mathrm{Ca}^{2+}$ ) can be replaced by cations from the transition metal series having the ability to catalyze reactions in a homogeneous medium.

Among the reactions of organic chemistry catalyzed by cations, we have the multicomponent reaction of Biginelli ${ }^{10}$ where reagents ethyl acetoacetate, benzaldehyde and urea react to give the dihydropyrimidinones $(\mathrm{DH}-$ PMs). These latter are well known to have important therapeutic and pharmaceutical properties; indeed they work as tension regulators and calcium blockers, ${ }^{11-13}$ moreover they show anti-HIV, ${ }^{14}$ anti-malarial, ${ }^{15}$ anti-epileptics, ${ }^{16}$ antitumors, ${ }^{17-20}$ anti-microbials, ${ }^{21}$ anti-inflammatories, ${ }^{22}$ anti-tubercular, ${ }^{23-24}$ anti-bacterials, ${ }^{25-26}$ and analgesic activities. $^{27}$

Given its importance, the Biginelli reaction has been the subject of several researches and was carried out in the presence of various catalysts such as Brønsted acids in homogeneous medium as $\mathrm{HCl}^{28-32} \mathrm{H}_{2} \mathrm{SO}_{4}{ }^{33-34}$ para-toluenesulfonic acid, ${ }^{35}$ methanesulfonic acid, ${ }^{36} \mathrm{HBF}_{4},{ }^{37}$ boric acid, ${ }^{38}$ phenylboronic acid, ${ }^{39}$ formylphenylboronic acid, ${ }^{40}$ carboxylic acid, ${ }^{41}$ molybdophosphoric acid, ${ }^{42}$ trifluoroacetic acid, ${ }^{43}$ Lewis acids in homogeneous medium ${ }^{44-47}$ as $\mathrm{FeCl}_{2}, \mathrm{FeCl}_{3}, \mathrm{NiCl}_{2}, \mathrm{CoCl}_{2}, \mathrm{Ce}\left(\mathrm{NO}_{3}\right)_{3}$, and heterogeneous catalysts as $\mathrm{Fe}_{2} \mathrm{O}_{3}$ nanoparticles, ${ }^{48}$ Nafion- $\mathrm{Ga}, \mathrm{Al}_{2} \mathrm{O}_{3}, \mathrm{TiO}_{2}$, $\mathrm{SiO}_{2}$ oxides. ${ }^{49-50}$

The Biginelli reaction was also carried out in the presence of montmorillonite of different origins, which has undergone various modifications and treatments. In the works of Singh, $\mathrm{ZrO}_{2}$-pillared clay was prepared and used in the Biginelli reaction under thermal and microwave heating. ${ }^{51}$ A commercial montmorillonite KSF (Aldrich Chemical Co., USA) was used under microwave conditions by Mitra. ${ }^{52} \mathrm{An}$ acid treatment using $\mathrm{HCl}$ was applied to a montmorillonite from India to prepare a mesoporous catalyst $^{53}$ applied for the synthesis of DHPMs. Montmorillonite was also used as a composite catalyst material for the Biginelli reaction using the montmorillonite-graphene oxide ${ }^{54}$ and bentonite/PS- $\mathrm{SO}_{3} \mathrm{H}$ composites. ${ }^{55}$

In the present work, an Algerian montmorillonite is used as a heterogeneous catalyst for the preparation of DHPMs by Biginelli reaction (Scheme 1). The main purpose is specifically to study the effect of the exchangeable cation on the yield and the kinetics of the reaction; a range of transition metal cations known for their catalytic activity in the homogeneous medium was selected, namely: $\mathrm{Cu}^{2+}, \mathrm{Ni}^{2+}, \mathrm{Cr}^{3+}, \mathrm{Co}^{2+}, \mathrm{Fe}^{2+}$ and $\mathrm{Fe}^{3+}$.

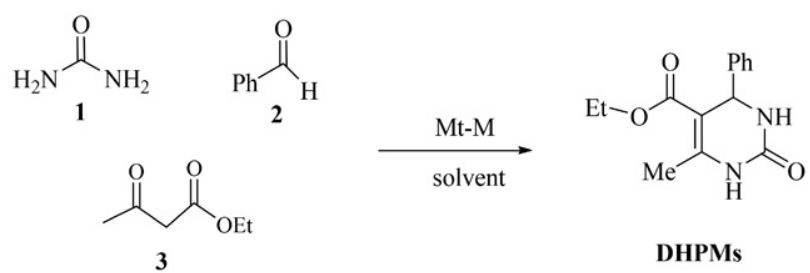

Mt: Montmorillonite

$\mathrm{M}:\left(\mathrm{Cu}^{2+}, \mathrm{Ni}^{2+}, \mathrm{Cr}^{3+}, \mathrm{Co}^{2+}, \mathrm{Fe}^{2+}\right.$ or $\left.\mathrm{Fe}^{3+}\right)$

Scheme 1. Biginelli reaction catalysed by exchanged montmorillonite.

\section{Materials and Methods}

\section{1. Chemicals and Apparatus}

The Algerian Na-montmorillonite (naturally, the exchangeable cation is $\mathrm{Na}^{+}$) comes from the deposit of Hammam Boughrara in Maghnia, located in western Algeria (hence the name Maghnite). It is supplied by ENOF Company (National company of useful substances and non-ferrous materials). Its chemical composition is: $69.4 \%$ $\mathrm{SiO}_{2}, 1.1 \% \mathrm{MgO}, 14.7 \% \mathrm{Al}_{2} \mathrm{O}_{3}, 0.8 \% \mathrm{~K}_{2} \mathrm{O}, 0.3 \% \mathrm{CaO}, 1.2 \%$ $\mathrm{Fe}_{2} \mathrm{O}_{3}, 0.5 \% \mathrm{Na}_{2} \mathrm{O}, 0.2 \% \mathrm{TiO}_{2}, 0.05 \%$ As and $11 \%$ loss of ignition. ${ }^{56}$

$\mathrm{X}$-ray diffraction (XRD) experiments were performed with a D8 Advance Bruker AXS diffractometer with $\mathrm{CuKa}$ radiation equipped with a curved graphite monochromator. The data were collected in the $2 \theta$ range of $10-80^{\circ}$ with a step size of $0.03^{\circ}$ and a count time of 2 s per step. The cation exchange capacity CEC was determined by the titration of the exchanged cation in solution by using atomic absorption on a Perkin-Elmer Analyst 400 device, before and after the exchange operation. Then, the amount of exchanged cation was expressed relatively to the mass of clay used in the exchange operation.

All reactions were monitored by analytical thin-layer chromatography (TLC) and visualized by UV light (254$264 \mathrm{~nm}$ ). Melting points were determined with a Kofler bench. Infrared (IR) spectra were recorded on a Shimadzu Fourier transform infrared spectrometer. Nuclear Magnetic Resonance (NMR) spectroscopy was registered on an Advance Bruker apparatus (600 MHz). Chemical shifts are reported in parts per million (ppm, $\delta$ ) downfield from tetramethylsilane. Proton coupling patterns are described as singlet $(\mathrm{s})$, doublet $(\mathrm{d})$, triplet $(\mathrm{t})$, quartet $(\mathrm{q})$ and multiplet $(\mathrm{m})$.

\section{2. Preparation of the Exchanged Montmorillonite}

For the exchange operation, $20 \mathrm{~g}$ of the natural Na-montmorillonite is stirred in $1 \mathrm{~L}$ of cation chloride solution $(1 \mathrm{M})$ for 10 hours at $60{ }^{\circ} \mathrm{C}$. This operation is 
repeated three times. The exchanged montmorillonite is then washed several times with distilled water to remove chlorides which are controlled by measuring the conductivity of the washing water and its $\mathrm{pH}$. Finally the final montmorillonite is oven-dried at $105^{\circ} \mathrm{C}$.

\section{3. Synthesis of 3,4-Dihydropyrimidin-2 (1H)-one (DHPM)}

A mixture of benzaldehyde $(6.5 \mathrm{mmol})$, ethyl acetoacetate $(9.5 \mathrm{mmol})$, urea $(6.25 \mathrm{mmol})$ and catalyst $(20 \%$ of benzaldehyde amount) was refluxed in solvent under magnetic stirring for an appropriate time. The progress of the reaction was monitored by TLC. The combined organic phases were washed with methanol to remove the impurities. The mixture was then filtered and the filtrate was collected. Thereafter, the methanol was evaporated to obtain a white solid. The crude products were purified by recrystallization from ethanol to get the desired product as a white solid.

\section{Results and Discussion}

\section{1. Characterization of the Exchanged Montmorillonite}

\section{1. 1. XRD Characterization}

Figure 1 shows the diffractograms of montmorillonite exchanged with various cations and compared to the

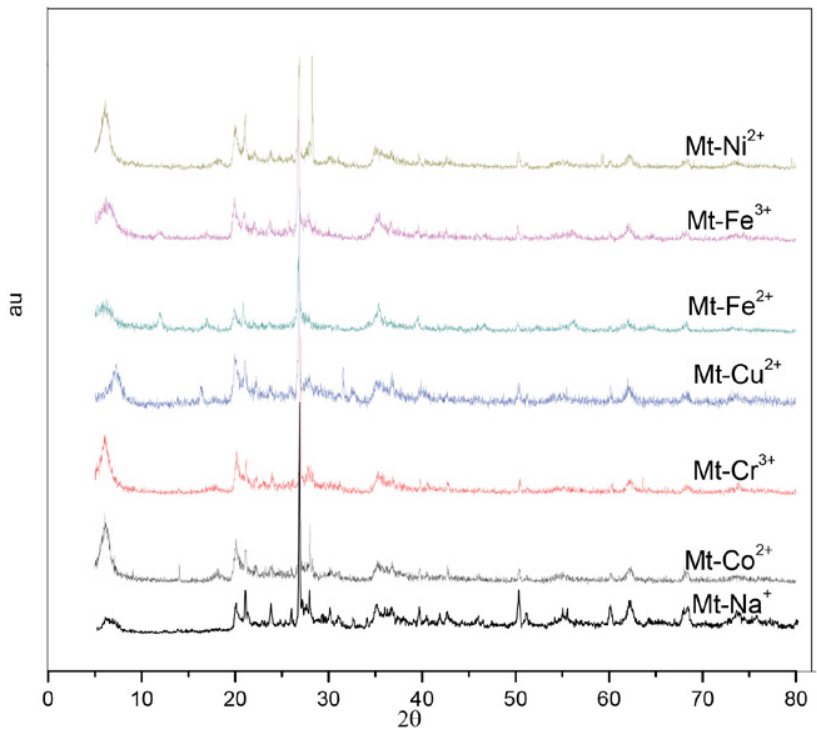

Figure 1. XRD diffractograms of montmorillonite exchanged with different cations. base montmorillonite exchanged with $\mathrm{Na}^{+}$characterized by the peaks $\left(2 \theta=6.22^{\circ}, 26^{\circ}, 35^{\circ}\right.$ and $\left.50^{\circ}\right)$.

Overall, we note that the cationic exchange did not alter the structure, only the angle $2 \theta$ shifts at the characteristic value of each cation; this leads to a change of the basal spacing $\mathrm{d}_{001}$ characterizing the interfoliar space, which can be calculated from the following Bragg equation:

$$
\mathrm{d}_{001}=\frac{\lambda}{2 \cdot \sin (\theta)}
$$

Note that the value of $\mathrm{d}_{001}$ is a function of cation solvation degree, i.e. the number of water layers surrounding each cation. Table 1 shows the values of the distance $d_{001}$ and the angle $2 \theta$ corresponding to each cation.

\section{1. 2. Cation Exchange Capacity}

For the cation exchange capacity (CEC), the obtained results are summarized in Table 2.

Table 2. Values of the cation exchange capacity.

\begin{tabular}{lc}
\hline Mt-M & CEC ( meq/100 g) \\
\hline${\mathrm{Mt}-\mathrm{Cu}^{2+}}^{2+}$ & 47.40 \\
${\mathrm{Mt}-\mathrm{Co}^{2+}}^{2+}$ & 111.60 \\
$\mathrm{Mt}^{2} \mathrm{Ni}^{2+}$ & 50.60 \\
$\mathrm{Mt}-\mathrm{Fe}^{2+}$ & 112.60 \\
$\mathrm{Mt}-\mathrm{Fe}^{3+}$ & 108.10 \\
$\mathrm{Mt}-\mathrm{Cr}^{3+}$ & 45.10 \\
\hline
\end{tabular}

In Table 2, we note that the highest CEC values are obtained for montmorillonite exchanged with iron(II) $\left(\mathrm{Fe}^{2+}\right)$, cobalt(II) $\left(\mathrm{Co}^{2+}\right)$ and iron(III) $\left(\mathrm{Fe}^{3+}\right)$; the CEC increases in this order: $\mathrm{Fe}^{2+}>\mathrm{Co}^{2+}>\mathrm{Fe}^{3+}>\mathrm{Ni}^{2+}>\mathrm{Cu}^{2+}>$ $\mathrm{Cr}^{3+}$. Eberl ${ }^{57}$ explained this behavior by the fact that the cation selectivity and cation fixation in clay depend on two competing forces: the first one is the attraction force of the cation for its hydration shell and the second is the attraction force of the cation for clay surfaces, thus the selectivity varies as these forces are different for each cation and the fixation occurs when the second force is greater than the first one.

\section{2. Characteristics of 3,4-Dihydropyrimidin- 2(1H)-one (DHPM)}

The analytical and spectroscopic data of the final product DHPM are: m.p. $205-207{ }^{\circ} \mathrm{C}\left(\mathrm{lit}^{58}: 206{ }^{\circ} \mathrm{C}\right)$. IR (KBr) v: 3235, 3103, 2942, 1718, 1695, 1593, $1216 \mathrm{~cm}^{-1}$.

Table1. Basal spacing $\mathrm{d}_{001}$ and $2 \theta$ angle for each cation.

\begin{tabular}{|c|c|c|c|c|c|c|c|}
\hline Mt-M & Mt-Na ${ }^{+}$ & Mt-Fe ${ }^{3+}$ & Mt-Fe ${ }^{2+}$ & $\mathrm{Mt}-\mathrm{Co}^{2+}$ & Mt-Cr ${ }^{3+}$ & $\mathrm{Mt}-\mathrm{Cu}^{2+}$ & $\mathrm{Mt}-\mathrm{Ni}^{2+}$ \\
\hline $2 \theta\left(^{\circ}\right)$ & 5.84 & 6.24 & 6.18 & 6.27 & 6.1 & 7.19 & 6.1 \\
\hline $\mathrm{d}_{001}(\AA)$ & 15.12 & 14.15 & 14.28 & 14.08 & 14.48 & 12.28 & 14.48 \\
\hline
\end{tabular}


${ }^{1} \mathrm{H}$ NMR (300 MHz, $\left.\mathrm{CDCl}_{3}\right) \delta 1.24(\mathrm{t}, 3 \mathrm{H}), 2.35(\mathrm{~s}, 3 \mathrm{H})$, $4.09(\mathrm{q}, 2 \mathrm{H}), 5.30(\mathrm{~s}, 1 \mathrm{H}), 5.89(\mathrm{~s}, 1 \mathrm{H}), 7.09-7.26(\mathrm{~m}, 5 \mathrm{H})$, $8.28(\mathrm{~s}, 1 \mathrm{H})$.

\section{3. Effect of the Exchanged Cation on Biginelli Reaction}

The Biginelli reaction was carried out in the presence of the montmorillonite used as a heterogeneous catalyst while being exchanged with different cations, a comparison with the conventional homogeneous catalyst in the presence of $\mathrm{HCl}$ was also performed. The results are shown in Table 3 in terms of the reaction time and yield; they clearly show that the highest yield was obtained by the $\mathrm{Mt}-\mathrm{Fe}^{3+}$ (60\%), followed by the $\mathrm{Mt}-\mathrm{Co}^{2+}(57 \%)$, the $\mathrm{Mt}-\mathrm{Fe}^{2+}$ is in the third position, then the other three exchanged montmorillonites with chromium, nickel and copper give very similar yields. These results are primarily related to the high cation exchange capacity with $\mathrm{Fe}^{3+}$ and $\mathrm{Co}^{2+}$ and to the electronegativity of the cations $\left(\mathrm{Co}^{2+}\right.$ and $\mathrm{Fe}^{3+}$ are more electronegative than $\mathrm{Fe}^{2+}$ ), which directly influences the acidity of the metal cations. Note that the use of $\mathrm{Mt}^{-\mathrm{Na}^{+}}$leads to a very low yield (13\%) with a very long reaction time $(32 \mathrm{~h})$.

As can be seen, the use of montmorillonite exchanged with $\mathrm{Fe}^{3+}$ and $\mathrm{Co}^{2+}$ as a heterogeneous catalysts produces higher yields ( $60 \%$ and $57 \%$, respectively) than the classical Biginelli method in homogeneous medium $(56 \%)$ (catalysis in the presence of $\mathrm{HCl}$ ). This is a very interesting result; it shows that the proposed heterogeneous catalysts $\left(\mathrm{Mt}_{-} \mathrm{Fe}^{3+}\right.$ and $\mathrm{Mt}-\mathrm{Co}^{2+}$ ) are as efficient if not better than the homogeneous $\mathrm{HCl}$ catalyst considering their other advantages as well (easy to recover from the reaction medium and to regenerate, they can also be used in small amounts, low cost and eco-friendly).

Table 3. Effect of the exchanged cation on Biginelli reaction.

\begin{tabular}{|c|c|c|}
\hline Catalyst & Time (h) & Yield (\%) \\
\hline 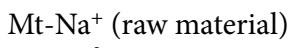 & 32 & 13 \\
\hline $\mathrm{Mt}-\mathrm{Cu}^{2+}$ & 7 & 20 \\
\hline $\mathrm{Mt}-\mathrm{Co}^{2+}$ & 9 & 57 \\
\hline $\mathrm{Mt}-\mathrm{Ni}^{2+}$ & 9 & 20 \\
\hline $\mathrm{Mt}-\mathrm{Fe}^{2+}$ & 7 & 34 \\
\hline $\mathrm{Mt}-\mathrm{Fe}^{3+}$ & 8 & 60 \\
\hline $\mathrm{Mt}-\mathrm{Cr}^{3+}$ & 10 & 24 \\
\hline $\mathrm{HCl}$ & 7 & 56 \\
\hline Without catalyst & 11 & 16 \\
\hline
\end{tabular}

\section{4. Parameters Influencing the Reaction}

In order to establish the optimal conditions for the reaction, we carried out a series of experiments by varying the parameters influencing the reaction such as the catalyst amount, the solvents and the introduction order of the reagents.

\section{4. 1. Effect of the Catalyst Amount}

To improve the yields, we changed in this part the quantity of the catalyst, while limiting our study to the two catalysts that gave the highest yields, namely $\mathrm{Mt}-\mathrm{Fe}^{3+}$ and $\mathrm{Mt}-\mathrm{Co}^{2+}$. The obtained results are summarized in Table 4 . It is clear that the increase in the catalyst amount leads to an increase in yield; this can be explained by the increase of the active sites on the catalyst surface, which can fix more reagent molecules. The highest yield is obtained with the highest catalyst amount (60\% of catalyst). We note that beyond $60 \%$ of the catalyst, we have obtained a pasty mixture, difficult to stir and the reaction becomes impossible.

Table 4. Effect of the catalyst amount on the yield of the reaction.

\begin{tabular}{|c|c|c|c|}
\hline Catalyst & Catalyst amount (\%) & Time (h) & Yield (\%) \\
\hline $\mathrm{Mt}-\mathrm{Fe}^{3+}$ & 20 & 8 & 60 \\
\hline $\mathrm{Mt}-\mathrm{Fe}^{3+}$ & 40 & 7 & 68 \\
\hline $\mathrm{Mt}-\mathrm{Fe}^{3+}$ & 50 & 7 & 76 \\
\hline $\mathrm{Mt}-\mathrm{Fe}^{3+}$ & 60 & 7 & 86 \\
\hline $\mathrm{Mt}-\mathrm{Co}^{2+}$ & 20 & 9 & 57 \\
\hline $\mathrm{Mt}-\mathrm{Co}^{2+}$ & 40 & 8 & 62 \\
\hline $\mathrm{Mt}-\mathrm{Co}^{2+}$ & 50 & 8 & 69 \\
\hline $\mathrm{Mt}-\mathrm{Co}^{2+}$ & 60 & 8 & 73 \\
\hline
\end{tabular}

\section{4. 2. Effect of the Solvent}

Various solvents were used: ethanol, water, toluene and glacial acetic acid with $50 \%$ of catalyst. The results are summarized in the Table 5.

Table 5. Effect of the solvent on the yield of the reaction.

\begin{tabular}{|c|c|c|c|c|}
\hline \multirow[b]{2}{*}{ Solvent } & \multicolumn{2}{|c|}{ Mt-Fe ${ }^{3+}$} & \multicolumn{2}{|c|}{$\mathrm{Mt}-\mathrm{Co}^{2+}$} \\
\hline & Time (h) & Yield (\%) & Time (h) & Yield (\%) \\
\hline Ethanol & 7 & 76 & 8 & 69 \\
\hline Water & 7 & 44 & 8 & 36 \\
\hline Toluene & 5 & 62 & 7 & 65 \\
\hline Glacial acetic acid & 5 & 82 & 6 & 77 \\
\hline
\end{tabular}

The effect of the solvent is significant on both the kinetics and the yield of the reaction. In the presence of water as the solvent qualified as "clean solvent", we have unfortunately noticed a considerable drop in yield compared to the other solvents (Table 5), whatever the catalyst used. The glacial acetic acid is the best solvent in terms of yield than all other tested solvents as shown in Table 5 (82\% for $\mathrm{Mt}-\mathrm{Fe}^{3+}$ and $77 \%$ for $\left.\mathrm{Mt}-\mathrm{Co}^{2+}\right)$, this can be explained by the fact that the acid can play the dual role of solvent and catalyst. We note that the reaction in the presence of acetic acid without catalyst has given a yield of $40 \%$ for a reaction time of $10 \mathrm{~h}$. 


\section{4. 3. Effect of the Introduction Order of the Reagents}

In heterogeneous catalysis, it is well known that the adsorption of the reactants on the surface of the catalyst is an important and limiting step of the chemical reaction. Thus the introduction order of the reagents into the reaction medium becomes important. We therefore proceeded in three different processes with $\mathrm{Mt}-\mathrm{Fe}^{3+}(50 \%)$ each consisting of two steps: in the first step, one of the three reagents was stirred with $\mathrm{Mt}-\mathrm{Fe}^{3+}$ in the presence of the solvent for 2 hours to allow sufficient time for the adsorption phenomenon, in the second step, the other two reagents were added under refluxing conditions (Table 6). Note: As the acetic acid has a double role of catalyst and solvent, we use in this part ethanol as solvent in order to show only the catalytic effect of montmorillonite.

The obtained results show the importance of the introduction order of the reagents (Table 6): the yields and the kinetics obtained with the $3^{\text {rd }}$ and the $2^{\text {nd }}$ processes are the best ( $81 \%$ in $5 \mathrm{~h}$ and $81 \%$ in $6 \mathrm{~h}$, respectively) compared to the $1^{\text {st }}$ process $(68 \%$ in $7 \mathrm{~h})$ and to that where all reagents are introduced at the same time $(76 \%$ in $7 \mathrm{~h})$ (Table 4).
The obtained results are linked to the adsorption phenomenon of the molecules on the surface of the catalyst, indeed when all reagents are introduced simultaneously (Table 4, entry 3 ), there can be a competition of their adsorption on the catalyst, which can decrease their reactivity towards each other. According to the results in Table 6, we propose the following mechanism of the reaction (Scheme 2).

Urea (1) is a molecule with a carbonyl group and two nitrogen atoms related to this carbonyl. The $\delta+$ character of the carbonyl carbon atom is also accentuated by the presence of the two more electronegative nitrogen atoms. Consequently, the oxygen atom has a very high electron density which allows it to attack the electropositive site $(\mathrm{M})$ of montmorillonite; this step corresponds to the adsorption of urea on montmorillonite. According to Kappe ${ }^{59}$ the reaction of urea and benzaldehyde (2) affords the intermediate acyl imine $\mathbf{4}$ which is catalyzed and stabilized by Mt-M. The adsorption of ethyl acetoacetate (3) on montmorillonite leads to ethyl acetoacetate enolate (5). The addition of the latter $\mathbf{5}$ to the acyl imine provides $\mathbf{6}$. Finally, cyclisation and dehydration of $\mathbf{6}$ give the corresponding dihydropyrimidine (DHPM).

Table 6. Effect of introduction order of reagents.

\begin{tabular}{|c|c|c|c|c|c|}
\hline & \multicolumn{2}{|c|}{ First step } & \multicolumn{3}{|c|}{ Second step } \\
\hline & Reagents & $\begin{array}{l}\text { Operating } \\
\text { condition }\end{array}$ & Reagents & $\begin{array}{l}\text { Operating } \\
\text { condition }\end{array}$ & $\begin{array}{c}\text { Yield } \\
(\%)\end{array}$ \\
\hline Process 1 & benzaldehyde + Mt-Fe ${ }^{3+}$ & stirring, $2 \mathrm{~h}$ & ethyl acetoacetate + urea & reflux, $7 \mathrm{~h}$ & 68 \\
\hline Process 2 & ethyl acetoacetate $+\mathrm{Mt}-\mathrm{Fe}^{3+}$ & stirring, $2 \mathrm{~h}$ & benzaldehyde + urea & reflux, $6 \mathrm{~h}$ & 81 \\
\hline Process 3 & urea $+\mathrm{Mt}^{-\mathrm{Fe}^{3+}}$ & stirring, $2 \mathrm{~h}$ & $\begin{array}{l}\text { benzaldehyde }+ \\
\text { ethyl acetoacetate }\end{array}$ & reflux, $5 \mathrm{~h}$ & 81 \\
\hline
\end{tabular}
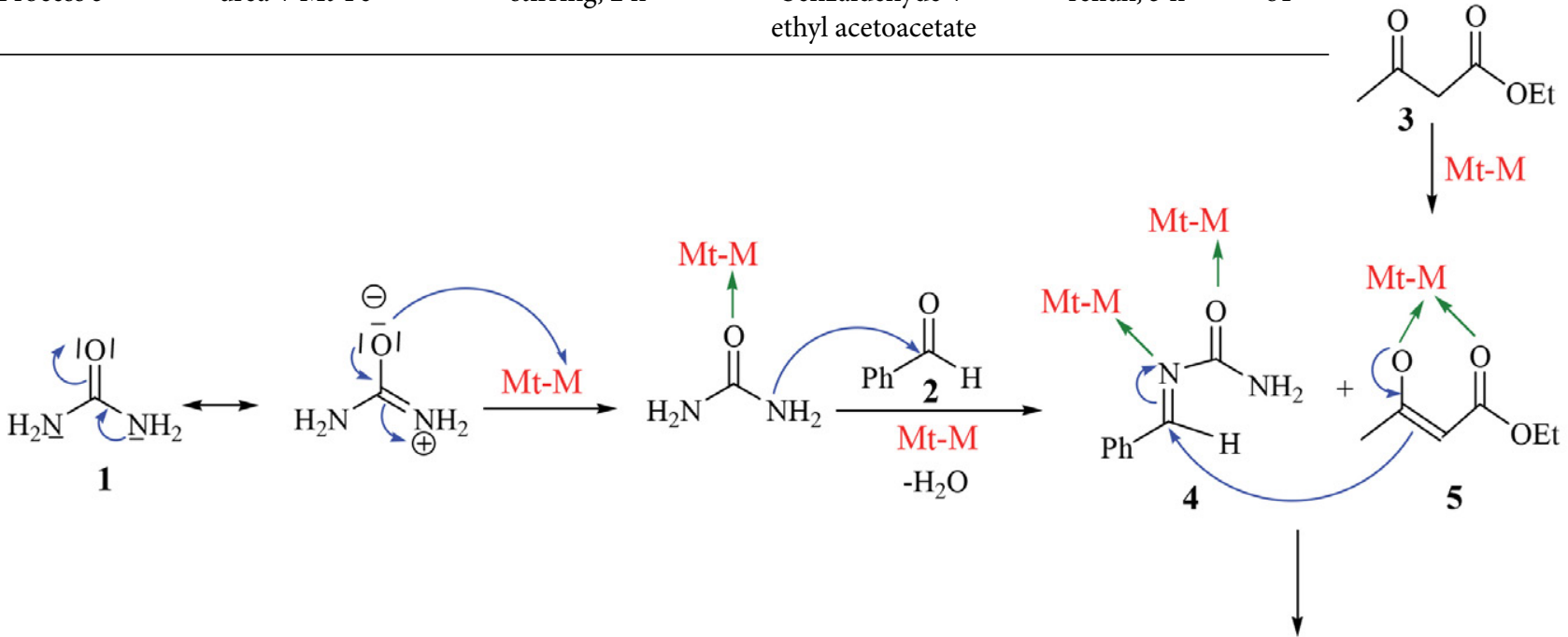

Scheme 2. Suggested mechanism of the reaction.<smiles>CCOC(=O)C1=C(C)NC(=O)NC1c1ccccc1</smiles>

DHPMs<smiles>CCOC(=O)C(C(C)=O)C(NC(N)=O)c1ccccc1</smiles> 
Overall, the obtained yields in ethanol as the solvent are very attractive and show that the exchanged montmorillonite which is a low cost, natural, eco-friendly and abundant material, competes favourably with other costly heterogeneous catalysts such as polystyrene-poly(ethylene glycol) resin-supported sulfonic acid, ${ }^{60}$ sulfonic acid-functionalized polypropylene fibers, ${ }^{61}$ Nafion-Ga, ${ }^{62}$ $\mathrm{ZnO}$ nanoparticles on SBA- $15^{63}$ and even with some homogeneous catalysts such as Co phthalocyanines, ${ }^{64}$ copper complexes, ${ }^{65}$ and $\mathrm{Hf}(\mathrm{OTf}){ }_{4}{ }^{66}$ (Table 7).

Table 7. Comparison between $\mathrm{Mt}-\mathrm{Fe}^{3+}$ and other catalysts reported in the literature.

\begin{tabular}{|c|c|c|}
\hline Catalyst & Time & $\begin{array}{l}\text { Yield (\%) } \\
\text { in ethanol }\end{array}$ \\
\hline 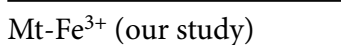 & $5 \mathrm{~h}$ & 81 \\
\hline PS-PEG-SO ${ }_{3} \mathrm{H}^{60}$ & $10 \mathrm{~h}$ & 80 \\
\hline PPF-SO ${ }_{3} \mathrm{H}^{61}$ & $8 \mathrm{~h}$ & 81 \\
\hline Nafion-Ga ${ }^{62}$ & $1 \mathrm{~h}$ & 84 \\
\hline $\mathrm{ZnO@SBA-15^{63 }}$ & $150 \mathrm{~min}$ & 96 \\
\hline Co phthalocyanines ${ }^{64}$ & $16 \mathrm{~h}$ & 10 \\
\hline NHC copper complexes ${ }^{65}$ & $24 \mathrm{~h}$ & 39 \\
\hline $\mathrm{Hf}(\mathrm{OTf})_{4}^{66}$ & $9 \mathrm{~h}$ & 88 \\
\hline
\end{tabular}

\section{Conclusion}

Montmorillonite is a natural heterogeneous catalyst, abundant, inexpensive and conforms to the concept of the green chemistry. In this work, the Biginelli reaction which consists of the preparation of dihydropyrimidinone from ethyl acetoacetate, benzaldehyde and urea, is carried out in the presence of an Algerian montmorillonite exchanged with different cations, as heterogeneous catalyst. Our study focuses mainly on the effect of the cation exchanged. Various cations were used $\left(\mathrm{Cu}^{2+}, \mathrm{Ni}^{2+}, \mathrm{Cr}^{3+}, \mathrm{Co}^{2+}, \mathrm{Fe}^{2+}\right.$ and $\mathrm{Fe}^{3+}$ ) and the montmorillonite exchanged with the $\mathrm{Fe}^{3+}$ and $\mathrm{Co}^{2+}$ showed high and satisfactory catalytic properties as they give pure final products with high yields, thus competing with the homogeneous acid catalysts which are dangerous, toxic and corrosive. The effect of the introduction order of the reagents into the reaction medium on the performance of the reaction is studied for the first time for montmorillonite in this work and we have shown that this order plays an important role and allows improving the yield and the kinetics of the reaction.

\section{References}

1. Y. Nishina, J. Syn. Org. Chem. Jpn. 2013, 71, 1307-1308.

DOI:10.5059/yukigoseikyokaishi.71.1307

2. Y. Liu, G. Zhao, D. Wang, Y. Li, Natl. Sci. Rev. 2015, 2, 150166. DOI:10.1093/nsr/nwv014
3. H. Göksu, Y. Yıldız, B. Çelik, M. Yazıcı, B. Kılbaş, F. Şen, ChemistrySelect 2016, 1, 953-958.

DOI:10.1002/slct.201600207

4. N. Kaur, D. Kishore, Chem. Pharm. Res. 2012, 4, 991-1015.

5. C. Liu, P. Wu, Y. Zhu, L. Tran, Chemosphere 2016, 144, 10261032. DOI:10.1016/j.chemosphere.2015.09.063

6. S. Yang, Z. Huang, P. Wu, Y. Li, X. Dong, C. Li, N. Zhu, X. Duan, Appl. Catal. B-Environ. 2020, 260, 118129.

DOI:10.1016/j.apcatb.2019.118129

7. S. Zhu, M. Xia, Y. Chu, M. A. Khan, W. Lei, F. Wang, Structure. Appl. Clay Sci. 2019, 169, 40-47.

DOI:10.1016/j.clay.2018.12.017

8. E. G. Ralph, Clay Mineralogy, 2nd Ed., McGraw-Hill, New York, 1968.

9. F. Effenberger, M. Schweizer, W. S. Mohamed, J. Appl. Polym. Sci. 2009, 112, 1572-1578. DOI:10.1002/app.29605

10. P. Biginelli, Gazz. Chim. Ital. 1893, 23, 360-416.

11. C. A. Sehon, G. Z. Wang, A. Q. Viet, K. B. Goodman, S. E. Dowdell, P. A. Elkins, S. F. Semus, L. J. Jolivette, S. Kirkpatrick, T. Yi, L. Wright, G. K. Smith, D. J. Behm, R. Bentley, C. P. Doe, E. Hu, D. Lee, J. Med. Chem. 2008, 51, 6631-6634. DOI:10.1021/jm8005096

12. R. V. Chikhale, R. P. Bhole, P. B. Khedekar, Eur. J. Med. Chem. 2009, 44, 3645-3653. DOI:10.1016/j.ejmech.2009.02.021

13. O. Alam, S. A. Khan, N. Siddiqui, W. Ahsan, S. P. Verma, S. J. Gilani, Eur. J. Med. Chem. 2010, 45, 5113-5119.

DOI:10.1016/j.ejmech.2010.08.022

14. A. D. Patil, N. V. Kumar, W. C. Kokke, F. Mark, M. F. Bean, A. J. Freyer, S. Mai, A. Truneh, B. Carte, J. Org. Chem. 1995, 60, 1182-1188. DOI:10.1021/jo00110a021

15. A. N. Chiang, J. C. Valderramos, R. Balachandran, R. J. Chovatiya, B. P. Mead, C. Schneider, S. L. Bell, M. G. Klein, D. M. Huryn, X. S. Chen, B. W. Day, D. A. Fidock, P. Wipf, J. L. Brodsky, Bioorg. Med. Chem. 2009, 17, 1527-1530.

DOI:10.1016/j.bmc.2009.01.024

16. R. W. Lewis, J. Mabry, J. G. Polisar, K. P. Eagen, B. Ganem, G. P. Hess, Biochemistry 2010, 49, 4841-4851. DOI:10.1021/bi100119t

17. B. R. Kumar, G. Sankar, R. Nasir Baig, S. Chandrashekaran, Eur. J. Med. Chem. 2009, 44, 4192-4198.

DOI:10.1016/j.ejmech.2009.05.014

18. D. A. Ibrahim, A. M. El-Metwally, Eur. J. Med. Chem. 2010, 45, 1158-1166. DOI:10.1016/j.ejmech.2009.12.026

19. H. Y. Kaan, V. Ulaganathan, O. Rath, H. Prokopcová, D. Dallinger, C. O. Kappe, F. Kozielski, J. Med. Chem. 2010, 53, 5676-5683. DOI:10.1021/jm100421n

20. O. C. Agbaje, O. O. Fadeyi, S. A. Fadeyi, Bioorg. Med. Chem. Lett. 2011, 21, 989-992. DOI:10.1016/j.bmcl.2010.12.022

21. E. Rajanarendar, M. N. Reddy, K. R. Murthy, K. G. Reddy, S. Raju, M. Srinivas, B. Praveen, M. S. Rao, Bioorg. Med. Chem. Lett. 2010, 20, 6052-6055.

22. S. N. Mokale, S. S. Shinde, R. D. Elgire, Bioorg. Med. Chem. Lett. 2010, 20, 4424-4446.

23. V. Virsodia, R. R. Pissurlenkar, D. Manvar, C. Dholakia, P. Adlakha, A. Shah, E. C. Coutinho, Eur. J. Med. Chem. 2008, 43, 2103-2115. DOI:10.1016/j.ejmech.2007.08.004 
24. A. Trivedi, V. R. Bhuva, B. H. Dholariya, D. K. Dodiya, V. B. Kataria, V. H. Shah, Bioorg. Med. Chem. Lett. 2010, 20, 61006102. DOI:10.1016/j.bmcl.2010.08.046

25. M. B. Deshmukh, S. M. Salunkhe, D. R. Patil, P. V. Anbhule, Eur. J. Med. Chem. 2009, 44, 2651-2654.

DOI:10.1016/j.ejmech.2008.10.018

26. S. Chitra, D. Devanathan, K. Pandiarajan, Eur. J. Med. Chem. 2010, 45, 367-371. DOI:10.1016/j.ejmech.2009.09.018

27. Y. S. Sadanadam, M. M. Shetty, P. V. Diwan, Eur. J. Med. Chem. 1992, 27, 87-92. DOI:10.1016/0223-5234(92)90066-A

28. F. Aslanoglu, E. Akbas, M. Sönmez, B. Anil, Phosphorus Sulfur Silicon Relat. Elem. 2007, 182, 1589-1597.

DOI:10.1080/10426500701263554

29. I. O. Lebedyeva, M. V. Povstyanoy, V. M. Povstyanoy, O. G. Panasyuk, E. S. Guban, A. B. Ryabitskii, Monatsh. Chem. 2010, 141, 997-1000. DOI:10.1007/s00706-010-0354-9

30. L. F. Valverde, F. D. Cedillo, A. C. Luis, Monatsh. Chem. 2010, 141, 75-78. DOI:10.1007/s00706-009-0223-6

31. J. Svetlik, V. Kettmann, Tetrahedron Lett. 2011, 52, 1062-1066. DOI:10.1016/j.tetlet.2010.12.051

32. H. Cho, Y. Nishimura, Y. Yasui, Tetrahedron 2011, 67, 26612669. DOI:10.1016/j.tet.2011.01.092

33. Z. Hassani, M. R. Islami, M. Kalantari, Bioorg. Med. Chem. Lett. 2006, 16, 4479-4482. DOI:10.1016/j.bmcl.2006.06.038

34. K. A. Dilmaghan, B. Zeynizadeh, M. Yari, Phosphorus Sulfur Silicon Relat. Elem. 2009, 184, 1722.

DOI:10.1080/10426500802293153

35. J. Tongshou, Z. Suling, L. Tongshuang, Synth. Commun. 2002, 32, 1847-1851.

36. T. S. Jin, H. X. Wang, C. Y. Chun-Yong Xing, X. L. Li, Synth. Commun. 2004, 34, 3009-3016. DOI:10.1081/SCC-200026660

37. W. Y. Chen, S. D. Quin, J. R Jin, Catal. Commun. 2007, 8, 123-126. DOI:10.1016/j.catcom.2006.05.026

38. S. Tu, F. Fang, C. Miao, H. Jiang, Y. Feng, Tetrahedron Lett. 2003, 44, 6153-6155. DOI:10.1016/S0040-4039(03)01466-7

39. A. Debache, B. Boumoud, M. Amimour, Tetrahedron Lett. 2006, 47, 5697-5699. DOI:10.1016/j.tetlet.2006.06.015

40. J. Martínez, S. Romero-Vega, R. Abeja-Cruz, Int J Mol Sci. 2013, 14, 2903-2915. DOI:10.3390/ijms14022903

41. S. Noreen, S. Perveen, M. N. Khan, A. Nazeer, M. A. Khan, M. A. Munawar, R. Babar, F. Suhail, M. Azad, A. M. Bernardino, M. S. Dos Santos, Asian J. Chem. 2013, 25, 4770-4772. DOI:10.14233/ajchem.2013.14094

42. M. M. Heravi, K. Bakhtiari, F. Bamoharram, Catal. Commun. 2006, 7, 373-376. DOI:10.1016/j.catcom.2005.12.007

43. M. R. Mohammadizadeh, N. Firoozi, e-J. Chem. 2011, 8, S266-S270. DOI:10.1155/2011/751282

44. J. Lu, Y. Bai, Synthesis 2002, 4, 466-447.

DOI:10.1055/s-2002-20956

45. M. Adib, K. Ghanbary, M. Mostofi, M. Ganjali, Molecules 2006, 11, 649-654. DOI:10.3390/11080649

46. M. Majd, K. Saidi, H. Khabazzadeh, Phosphorus Sulfur Silicon Relat.Elem.2010,185,325. DOI:10.1080/10426500902796931

47. L. M. Ramos, A. Y. Ponce de Leon y Tobio, M. R. dos Santos, H. C. B. de Oliveira, A. F. Gomes, F. C. Gozzo, A. L. de Olivei- ra, B. A. D. Neto, J. Org. Chem. 2012, 77, 10184-10193. DOI:10.1021/jo301806n

48. N. E. Masoud, S. J. Hoseini, F. Mohammadi, Chin. J. Catal. 2011, 32, 1484-1489.

49. G. K. S. Prakash, H. Lau, C. Panja, I. Bychinskaya, S. K. Ganesh, B. Zaro, T. Mathew, G. A. Olah, Catal. Lett. 2014, 144, 2012-2020. DOI:10.1007/s10562-014-1364-8

50. O. V. Fedorova, Y. A. Titova, A. Y. Vigorov, M. S. Toporova, O. A. Alisienok, A. N. Murashkevich, V. P. Krasnov, G. L. Rusinov, V. N. Charushin, Catal. Lett. 2016, 146, 493-498.

DOI:10.1007/s10562-015-1666-5

51. V. Singh, V. Sapehiyia, V. Srivastava, S. Kaur, Catal. Commun. 2006, 7, 571-578. DOI:10.1016/j.catcom.2005.12.021

52. A. K. Mitra, K. Banerjee, Synth. Lett. 2003, 10, 1509-1511. DOI:10.1055/s-2003-40828

53. A. Phukan, S. J. Borah, P. Bordoloi, K. SharmaBorah, $A d v$. Powder Technol. 2017, 28(6), 1585-1592. DOI:10.1016/j.apt.2017.03.030

54. D. P. Narayanan, A. Gopalakrishnan, Z. Yaakob, S. Sugunan, B. N. Narayanan, Arab. J. Chem. 2017, 10, 1-17.

55. R. J. Kalbasi, A. R. Massah, B. Daneshvarnejad, Appl. Clay Sci. 2012, 55, 1-9. DOI:10.1016/j.clay.2011.05.015

56. H. Khalaf, O. Bouras, V. Perrichon, Microporous Mater. 1997, 8, 141-150. DOI:10.1016/S0927-6513(96)00079-X

57. D. D. Eberl, Clays and Clay Minerals. 1980, 146, 493-498.

58. P. Salehi, M. Dabiri, M. A. Zolfigo, Tetrahedron Lett. 2003, 44, 2889-2891. DOI:10.1016/S0040-4039(03)00436-2

59. C. O. Kappe, J. Org. Chem. 1997, 62, 7201-7204. DOI:10.1021/jo971010u

60. Z. J. Quan, Y. X. Da, Z. Zhang, X. C. Wang, Catal. Commun. 2009, 10, 1146-1148. DOI:10.1016/j.catcom.2008.12.017

61. X. L. Shi, H. Yang, M. Tao, W. Zhang, RSC Adv. 2013, 3, 39393945. DOI:10.1039/c3ra23187a

62. G. K. S. Prakash, H. Lau, C. Panja, I. Bychinskaya, S. K. Ganesh, Catal. Lett. 2014, 144, 2012-2020.

DOI:10.1007/s10562-014-1364-8

63. D. Bhuyan, M. Saikia, Microporous Mesoporous Mater. 2018 , 256, 39-48. DOI:10.1016/j.micromeso.2017.06.052

64. R. Medyouni, W. Elgabsi, O. Naouali, A. Romerosa, S. A. AlAyed, L. Baklouti, N. Hamdi, Spectrochim. Acta Mol. Biomol. Spectrosc. 2016, 167, 165-174.

DOI:10.1016/j.saa.2016.04.045

65. R. Pawlowski, E. Zaorska, S. Staszko, A. Szadkowska, Appl. Organomet. Chem. 2018, 32, 4256-4266.

DOI:10.1002/aoc.4256

66. R. Kong, S. B. Han, J. Y. Wei, X. C. Peng, Z. B. Xie, S. S. Gong, Q. Sun, Molecules 2019, 24, 364-377.

DOI:10.3390/molecules24020364

Povzetek: 


\section{Povzetek}

$\mathrm{V}$ tem prispevku opisujemo kako smo $\mathrm{v}$ alžirskem montmorillonitu $(\mathrm{Mt})$ izvedli izmenjavo kationa $\mathrm{z}$ različnimi drugimi kationi iz družine prehodnih kovin, t.j. $\mathrm{Cu}^{2+}, \mathrm{Ni}^{2+}, \mathrm{Cr}^{3+}, \mathrm{Co}^{2+}, \mathrm{Fe}^{2+}$ and $\mathrm{Fe}^{3+}$; tako pripravljene heterogene katalizatorje smo uporabili pri Biginellijevi reakciji. Kationi, izbrani za izmenjavo, so znani po svojih katalitskih lastnostih v primerih homogene katalize. Glavni namen našega dela je bil študirati vpliv izmenjave kationa na izkoristek in kinetiko reakcije. Karakterizacijo montmorillonita smo izvedli z rentgensko praškovno difrakcijo, ki omogoča spremljanje spreminjanja razdalj $\mathrm{d}_{001} \mathrm{v}$ odvisnosti od izmenjanega kationa in hkrati tudi pokaže, če je med izmenjavo prišlo do spremembe strukture montmorillonita. Kationsko izmenjevalno kapaciteto (CEC) smo določili s titracijo izmenjanih kationov $\mathrm{z}$ atomsko absorpcijo. Produkt Biginellijeve reakcije smo karakterizirali z NMR, IR in z določitvijo tališča. Dodatno smo tudi raziskali vpliv vrstnega reda dodajanja reaktantov na izkoristek in kinetiko. Tako smo pokazali, da se lahko izmenjani montmorillonit ugodno kosa z ostalimi dražjimi hetero- in homogenimi katalizatorji. 